\title{
TOURISM IN COASTAL AREAS: ITS IMPLICATION TO IMPROVE ECONOMIC AND CULTURE ACCULTURATION (CASE STUDY IN GOA CHINA BEACH, MALANG)
}

\author{
I Komang ASTINA \\ State University of Malang, Faculty of Social Science, Geography Department, Indonesia, e-mail: komang.astina.fis@um.ac.id \\ SUMARMI* \\ State University of Malang, Faculty of Social Science, Geography Department, Indonesia, e-mail: sumarmi.fis@um.ac.id \\ Elya KURNIAWATI \\ State University of Malang, Faculty of Social Science, Sociology Department, Indonesia, e-mail: elya.kurniawati.fis@um.ac.id
}

\begin{abstract}
Citation: Astina, I.K., Sumarmi, \& Kurniawati, E. (2021). TOURISM IN COASTAL AREAS: ITS IMPLICATION TO IMPROVE ECONOMIC AND CULTURE ACCULTURATION (CASE STUDY IN GOA CHINA BEACH, MALANG). GeoJournal of Tourism and Geosites, 37(3), 740-746. https://doi.org/10.30892/gtg.37302-704
\end{abstract}

\begin{abstract}
The study aimed to determine: (1) tourism carrying capacity development in Goa China Beach (2) opportunities and challenges in developing Goa China (China Cave) Beach to improve the community's economy (3) cultural acculturation in communities around the coast of Goa China. Survey was use as main data collecting method in this research, followed by interview, observation and documentation. The results indicated that the beach carrying capacity is in a positive and strong condition. The attraction of the Goa China (China Cave) Beach is the natural beauty and myths that are believed by the community, causing an increase in the number of visitors on this beach compared to other beaches, especially at weekends.
\end{abstract}

Key words: tourism carrying capacity, economic improvement, cultural acculturation

\section{INTRODUCTION}

The tourism industry is needed to be developed because the activities carried out in the ecosystem have an impact on many economic sectors in society (Arintoko et al., 2020). The tourism sector can be used to encourage economic change (Jarvis et al., 2016), open up job opportunities (Purwanto et al., 2015), increase income (Ernawati et al., 2017) and increase the quality of life of local communities (Marlina al., 2020; Ramanda et al., 2020). One approach that can be used in the development and planning of tourism studies is the community-based approach model known as a participatory approach (Prabhakaran et al., 2014). The approach is based on the alignments of the local community to maintain the local culture and have an impact on improving the welfare (Ernawati et al., 2017; Keyim, 2018; Munien et al., 2019).

The community also has an important role in tourism development (Marlina et al., 2020; Sumarmi et al., 2020). The community will be encouraged to participate in tourism activities if the community knows the positive benefits of tourism (Suwantoro, 1997; Thomas, 2007). There are several development models of community-based empowerment, one of which is by increasing marketing and accessibility, improving quality and service through human resource development (Goodwin, 2002; Haywood, 1988; Timothy, 1999). Besides, the community can actively participate in spatial planning, spatial use and control of spatial use (Yankholmes, 2018). Beaches in South Malang are feasible to develop and have many advantages included: Lenggoksono Beach, Sendiki Beach, Goa China (China Cave) Beach, Bajul Mati Beach, Batu Bengkung Beach, Nganteb Beach, Selok Beach and Ngliyep Beach. The research was conducted to analyze the tourism development strategy of Goa China (China Cave) Beach in Malang Regency. Analyzing the key factors in the development of Goa China Beach tourism can be done through 2 stages: 1) identify factors that influence the development of Goa China Beach tourism and 2) determine several key factors in tourism development discussed with experts from marine tourism, institution, and literature study. The key factors referred are the potential objects of natural tourism attraction, management policies, demand for ecotourism, community participation, facilities and infrastructure, security, spatial tourism planning, promotion and marketing, institutional capacity, attraction management, economic contribution, culture (Damanik and Weber, 2006; Hilman and Kartika, 2020). The study aimed to determine: (1) tourism carrying capacity development in Goa China Beach (2) opportunities and challenges in developing Goa China (China Cave) Beach to improve the community's economy (3) cultural acculturation in communities around the coast of Goa China.

\section{METHODOLOGY}

The research used survey method with quantitative and qualitative analysis techniques. Bogdan and Taylor stated that qualitative methodology is a research procedure that produces descriptive data from observable behaviors (Moleong, 2004; Sugiyono, 2014). Therefore, qualitative research produces descriptive data from the implementation that occurs naturally. Data is divided into 2: primary and secondary data. Primary data was obtained through interviews and focus group 
discussions (FGD) with beach managers, homestay managers, seller, visitors, business owners around the coastal area. Observations were made at the beach area (Dyana Peak, a place to see sea view from the top of the cave), at homestay, and around the cave. Secondary data were obtained from villagers, sub-district and district government officers.

The analysis technique used SWOT analysis to analyze the environmental conditions of Goa China (China Cave) Beach internally and externally, formulate strengths, weaknesses, opportunities and threats including supporting and obstacle factors from the internal and external environment, the concept of developing Goa China beach tourism in Malang Regency, and making related data interpretations based on findings from the literature studies or related theories.

\section{RESULTS AND DISCUSSIONS}

The research subject is Goa China (China Cave) Beach located in Gedangan District, Malang Regency, about 58 kilometers from south of Malang City. The detail shown in Figure 1.

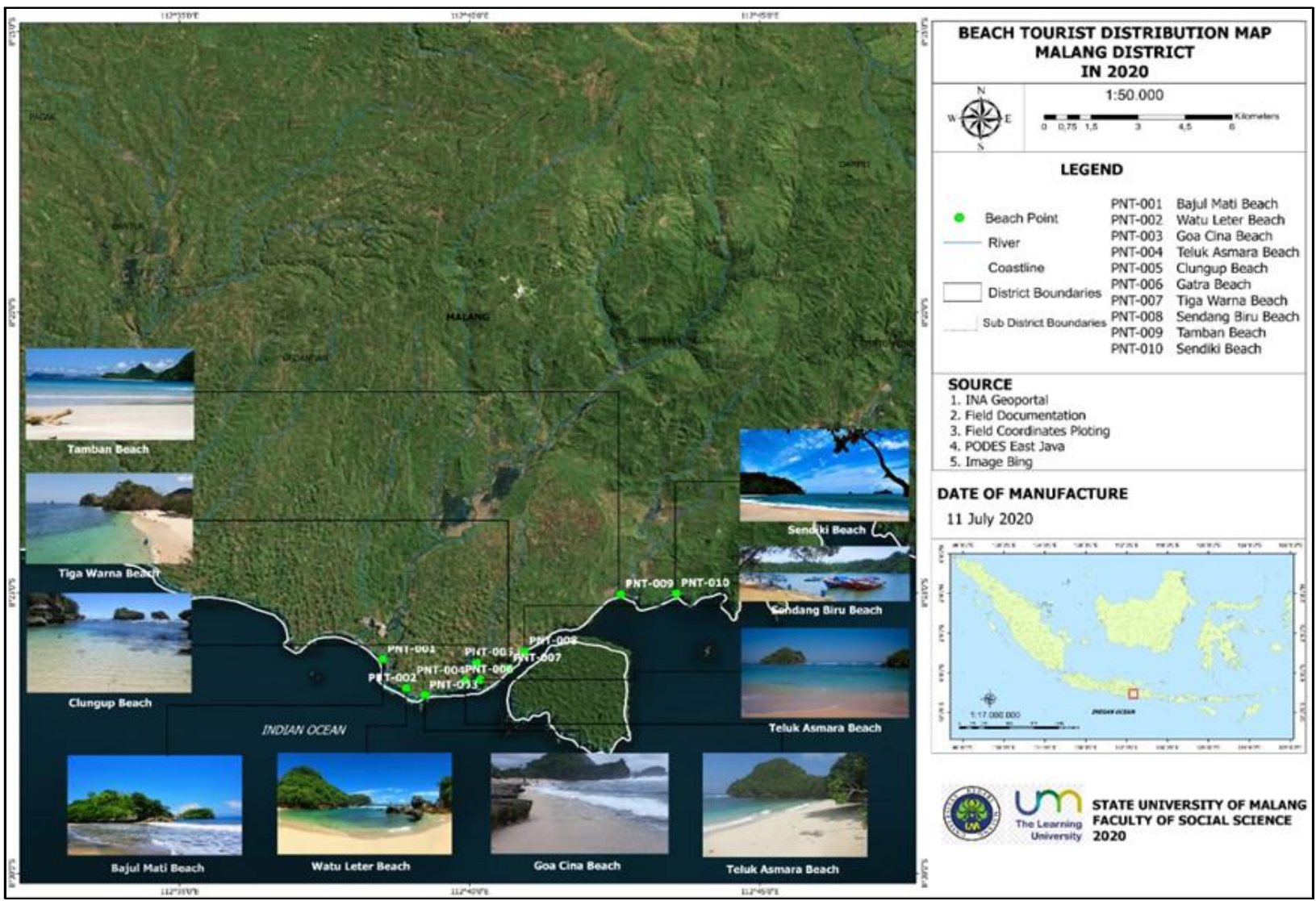

Figure 1. Goa China Beach and the Surrounding Beaches in Malang Regency

\section{Carrying Capacity of Goa China Beach Tourism Development}

The beach in the southern Java has characteristics of big waves which is different from the beaches in the northern part. It is due to the position of the south coast directly facing the Indian Ocean. In general, the south coast has steep beaches (cliff) and a relatively flat beach. The southern coast of Java in the East Java region has very varied cliffs. The

beach is dominated by limestone, but there

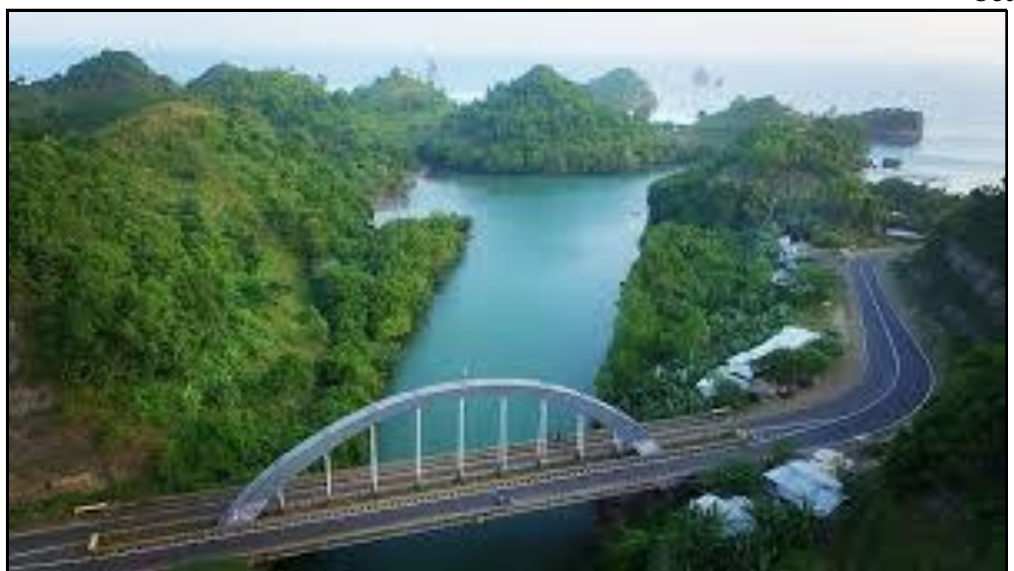

Figure 2. Bajul Mati Bridge to the Goa China Beach are high and low parts. In this low part, it is filled with volcanic sediments from the eruption of several volcanoes, such as Semeru and Kelud occurred in the last decades and years. It caused some beaches to have white and yellowish sand made from limestone, and there are black sand beaches made from volcanic breccia (Herlambang, 2004). Goa China (China Cave) Beach is located on the southern coast of Malang Regency, Tumpak Awu Hamlet, Sitiarjo Village, Sumbermanjing Wetan District. The beach has the cavity in the cliff with a depth of 8 meters and a height of 2 meters. The cavity was extensive and allowed anyone to enter directly into the Cave. 
The beach is famous because it has natural scenery, and the waves are pounding. The sand of Goa China Beach is sparkling white, and there are cembrit and ketapang trees along the coastline. There is also a view of some row of cliffs on the beach. Goa China (China Cave) is 50 meters on the right side of the beach. The Goa China (China Cave) Beach comes from limestone or coral from a natural change process. It can be seen from the cliff ruins in the coastal waters of islands and on the coastline of hills. Goa China (China Cave) Beach is separated by a hill that cuts the coastline from Watu Leter beach in the west. The eastern boundary is also separated by a hill from the coast of Teluk Asmara. Before entering Goa China (China Cave) Beach, there is a bridge called Bajul Mati Bridge opened in the mouth of the river. The bridge has a length of about 80 meters with a width of about 20 meters with two lanes (Figure 2). It has a pretty good architecture with curved poles in the middle of the bridge in a longitudinal position with a height of up to 20 meters. The bridge has a very distinctive and artistic mode. Goa China Beach is part of the South Coast, so it has strong ocean tides. However, the tides have unique waves, as it diverges from three directions: East, South and West and hit between Nyonya and Bantengan Islands, causing a clash. The islands were added beautiful on Goa China Beach (Figure 3).
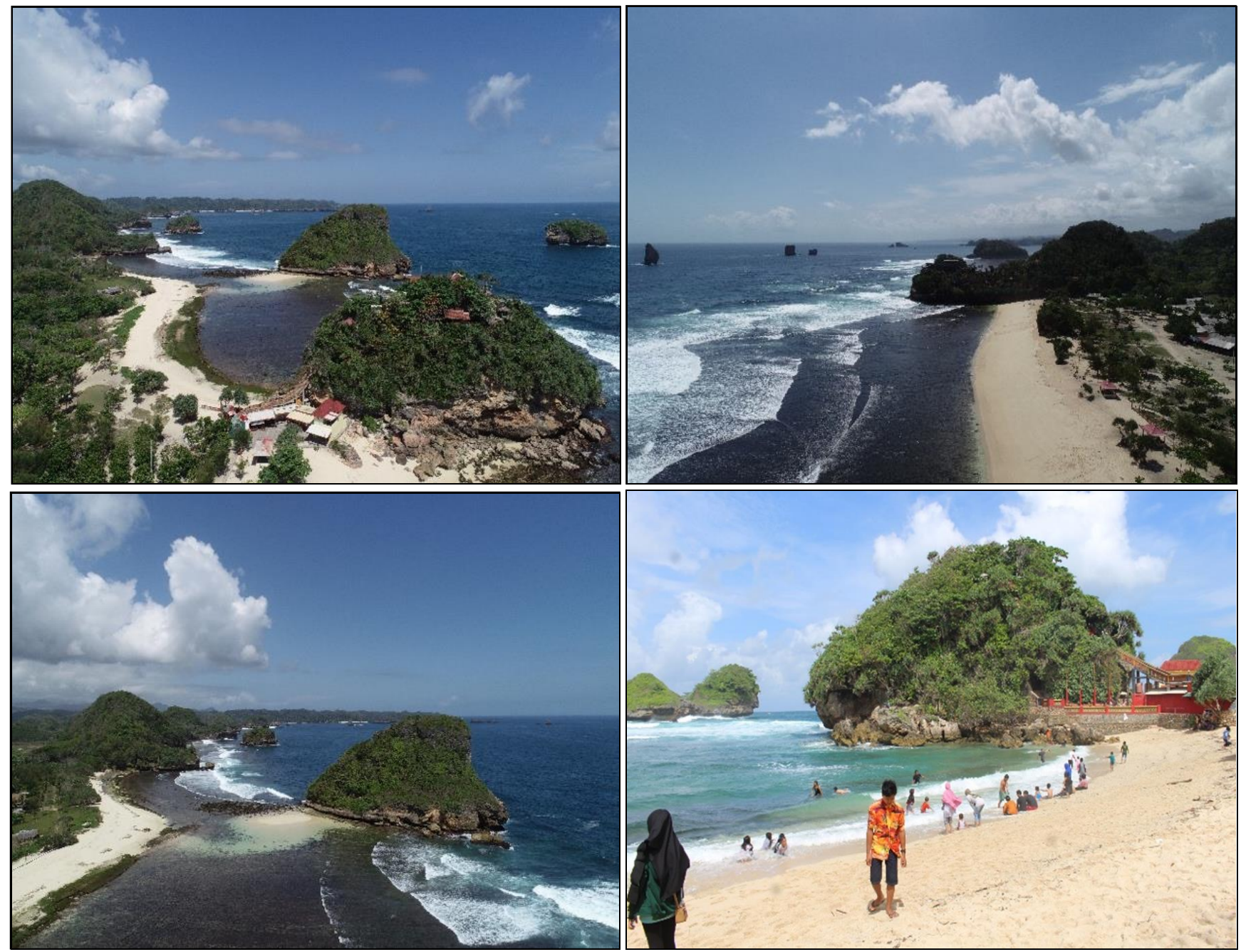

Figure 3. Beautiful Scenery at Goa China Beach

Goa China (China Cave) Beach is a great place for camping, and tourists are also allowed to do some beach sports such as beach volleyball and beach soccer. There are many facilities around the beach area such as stalls that sell food and drinks, prayer rooms, toilets and food stalls, parking lots. The beach has a unique cave that was once used by a monk from China. Local people usually use this cave for rituals of asking for blessings and luck by bringing papaya stems as a condition.

In general, there are several participations implemented by the community along with the coastal tourism of South Malang, such as Forest Village Community Organization (Lembaga Masyarakat Desa Hutan/LMDH) Tani Maju in charge of the development of Goa China Beach. Furthermore, there is the community participation as the members of the Youth Cares for the Archipelago Forest Organization (Paguyuban Pemuda Peduli Rimba Nusantara) were mostly immigrants from Dampit, Malang, and Blitar managed by the Local Government. Starting from borrowing money from a bank, the immigrant community then developed. Also, some people are members of the LMDH under Forest Management Organization (Perum Perhutani KPH) in Malang. The community also participated in managing tourism as ticketing collector, parking assistant, security guard, and also tourist guide. The ticket revenue is then paid to the village to be managed, stored, and partly given to Perhutani. Community participation along Goa China Beach Tourism tends to be dominated by the functional participation models. The model invited the community to develop, advise and plan the 
tourist destinations (Purnomo et al., 2020). Therefore, a local community organization was formed to appreciate the community participation, but decision-makers in planning tourist destinations were still dominated by parties outside the community (Kodir et al., 2019). The Income distribution of Perhutani can be seen in the Figure 4, and number of Beach Tourism in Sumbermanjing Wetan District can be seen in the Figure 5.

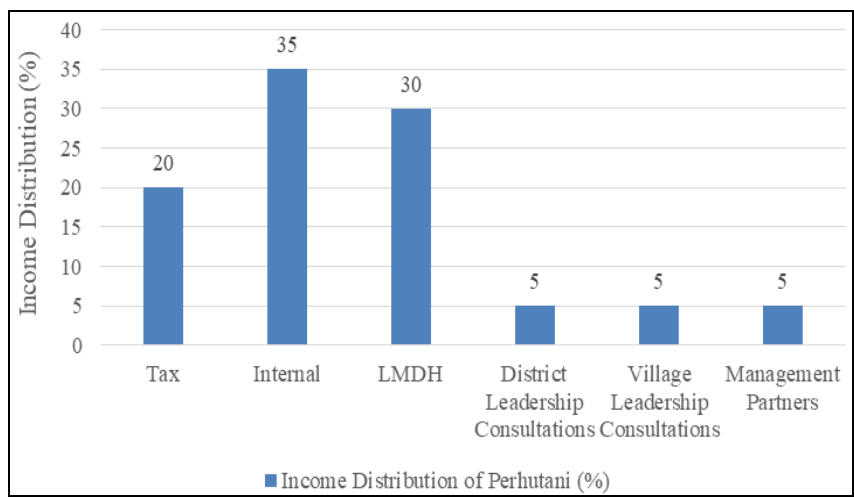

Figure 4. Perhutani Revenue Sharing (Ramanda et al, 2020)

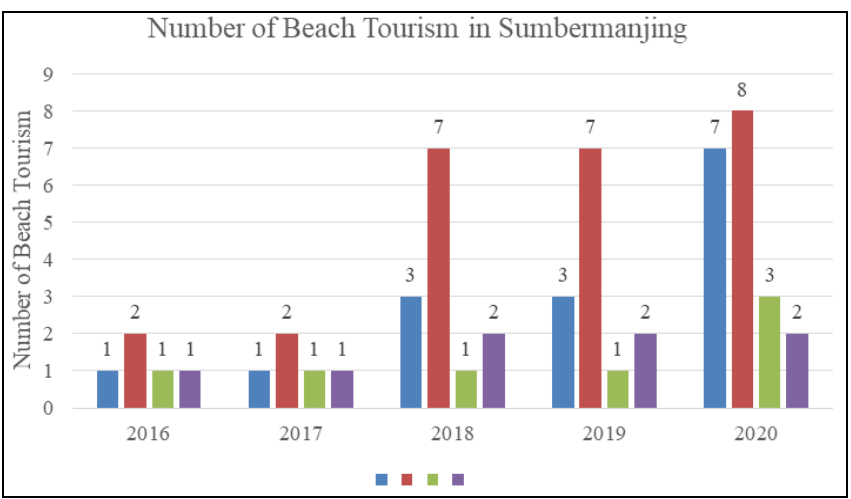

Figure 5. Number of Beach Tourism in Sumbermanjing Wetan District (Source: BPS, 2020)

\section{Opportunities and Challenges in Developing the Goa China Coast for the Community Economy Improvement}

The coastal area is a transitional area between the terrestrial ecosystem (sub-district administration area) and the sea (as far as 12 (twelve) nautical miles measured from the coastline) (Bengen, 2010). The tourism development strategy is carried out by developing attractions that include natural, cultural and human-made tourism that are integrated spatially by taking the global advantages and competitiveness through: a) identification of potential natural, cultural and humanmade tourist attractions; b) determine the potential for leading tourist attractions; c) establish a tourism development that is integrated with regional infrastructure development; d) developing tourism support activities; e) preserving the traditions or wisdom of local communities; and f) increasing guidance, counseling and training for the community and local artisans for tourism development. Several beaches and the contribution to improving the economy of the surrounding community can be seen in the following figure.

Table 1. Number of Restaurants and Kiosks in Sumbermanjing Wetan Sub-district (Source: BPS, 2020)

\begin{tabular}{|c|l|c|c|c|c|c|}
\hline \multirow{2}{*}{ No } & \multicolumn{2}{|c|}{ Villages } & \multicolumn{5}{c|}{ Year } \\
\cline { 3 - 8 } & & $\mathbf{2 0 1 6}$ & $\mathbf{2 0 1 7}$ & $\mathbf{2 0 1 8}$ & $\mathbf{2 0 1 9}$ & $\mathbf{2 0 2 0}$ \\
\hline 1 & Sitiarjo & 22 & 24 & 29 & 30 & 65 \\
\hline 2 & Tambakrejo & 21 & 24 & 26 & 26 & 67 \\
\hline 3 & Kedungbanteng & 17 & 17 & 17 & 17 & 23 \\
\hline 4 & Tambakasri & 125 & 126 & 129 & 133 & 140 \\
\hline 5 & Tegalrejo & 18 & 18 & 18 & 18 & 23 \\
\hline 6 & Ringinkembar & 19 & 19 & 19 & 19 & 27 \\
\hline 7 & Sumberagung & 19 & 19 & 19 & 19 & 24 \\
\hline 8 & Harjokuncaran & 36 & 36 & 36 & 36 & 41 \\
\hline 9 & Argotirto & 25 & 25 & 25 & 35 & 39 \\
\hline 10 & Ringinsari & 24 & 24 & 24 & 29 & 38 \\
\hline 11 & Druju & 28 & 28 & 28 & 34 & 35 \\
\hline 12 & Sumbermanjing Wetan & 43 & 43 & 43 & 44 & 44 \\
\hline 13 & Klepu & 23 & 23 & 23 & 23 & 23 \\
\hline 14 & Sekarbanyu & 20 & 20 & 20 & 23 & 25 \\
\hline 15 & Sidoasri & 23 & 26 & 29 & 29 & 33 \\
\hline \multicolumn{1}{|c|}{ Total } & 463 & 472 & 485 & 491 & 647 \\
\hline
\end{tabular}

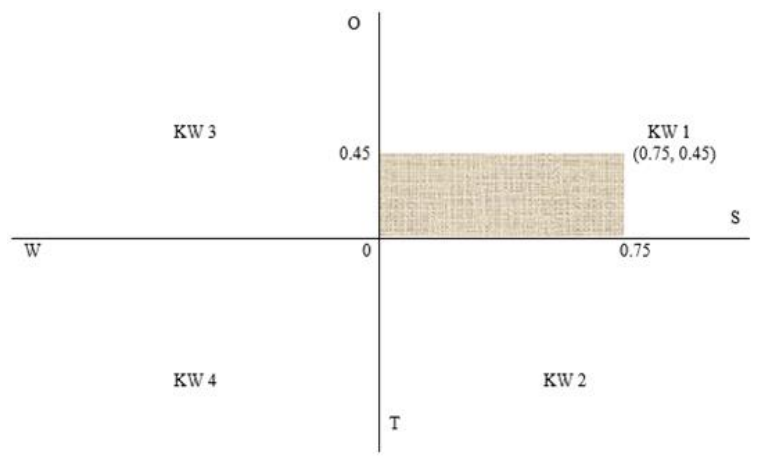

Figure 7. SWOT Analysis Quadrants for Goa China Beach

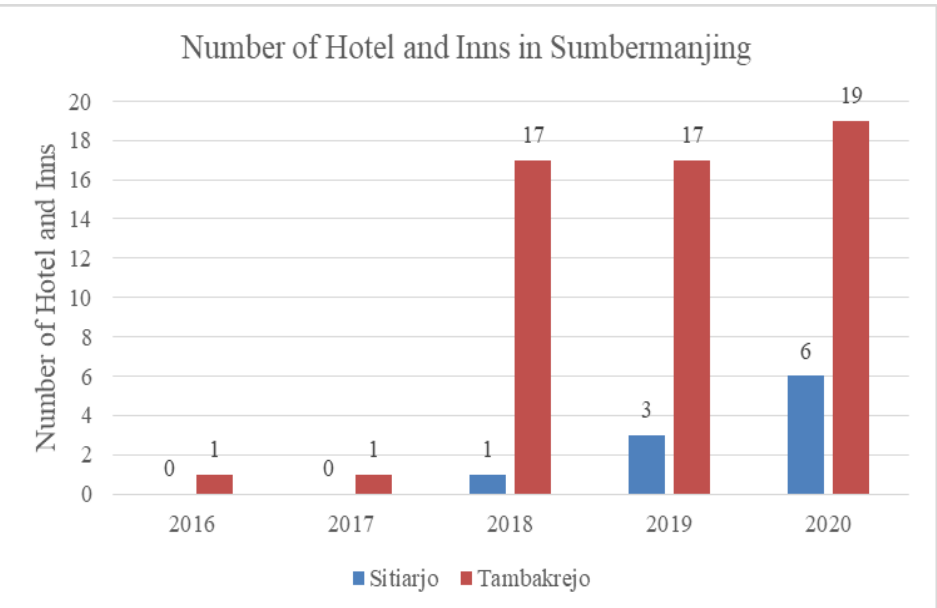

Figure 6. Number of Hotels and Inns in

Sumbermanjing Wetan Sub-district (Source: BPS, 2020)

Several villages did not have beaches, such are Kedungbanteng, Tegalrejo, Ringinkembar, Sumberagung, Harjokuncaran, Argotirto, Ringinsari, Druju, Sumbermanjing Wetan, Klepu and Sekarbanyu, but they have growth of restaurants and kiosks that shown in the following Table 1. Based on Figure 6 showed that only two villages, Sitiarjo and Tambakrejo, that have hotels and homestays while other villages did not have it. SWOT analysis was used to measure the strengths, weaknesses, opportunities and challenges in the development of Goa China Beach (Asmit et al., 2020). Based on IFAS and EFAS matrix in table 2, the SWOT analysis quadrant then used as shown in the following Figure 7. 
cannot be disturbed or changed, as well as intermediate rooms which are occupied by several homestay buildings. The outermost room is a path that connects the rooms and the entrance or gate to the hills of Goa China (China Cave).

The cave has an "anthropormic" concept that comes from nature in Javanese Hindu culture by using "wastra" or yellow and white cloth and a black and white square pattern. Trees are personified as "partners" who complement the existence of living things in this tourist attraction. There are stairs to the hill of Goa China, which was built based on Chinese architecture. It can be seen in the ornamentation dominance of red, as in the sacred buildings of the Chinese or Chinese community.

Goa (cave) is a natural condition in the karst area (Kodir, 2018). The cave is formed from the process of erosion and dissolving by water against lime (Dahuri et al., 2001). As a tourist attraction, the existence of Goa is its main attraction. The Chinese monk who died in Goa has given a name to the coastal area, which then branding this object in the development of tourism, especially in the Malang area. The concept of space (mandala) in the cave adopts the traditional Javanese spatial layout. The main room is Goa (cave) which is believed by local people to be a place of the hermitage.

Therefore, this place is sacred by residents and visitors. It can be seen from the facilities and infrastructure in flower beds and censer, as well as the altar. The existence of these facilities and infrastructure exists in Hindu, Javanese and Chinese rituals. The middle room (Madya) is a path on the eastern cliff of the hill from the gate to the door or mouth of the cave. In this space, there are three mythological animal statues found in Javanese, Hindu and Chinese cultures.

Artificially, the statue draws something creepy and is made of rock as the main material. The last room is the entrance or gate with the nuances of Chinese culture. The main object of this tourist area is Goa, the beach and sea view from the top of the hill. The combination of physical and cultural aspects is a tourist attraction (Kurniawati et al., 2020; Marlina et al., 2020). The main gate was built to enter these two objects. The gate was built in Chinese architecture as a gate like a place for ritual activities. The gate further adds to the nuance of being a spiritual tourism object in Malang area as well as for national tourists. Along with the development of international tourism, Goa China has become an attraction for international tourism, especially from countries with a background of Chinese culture.

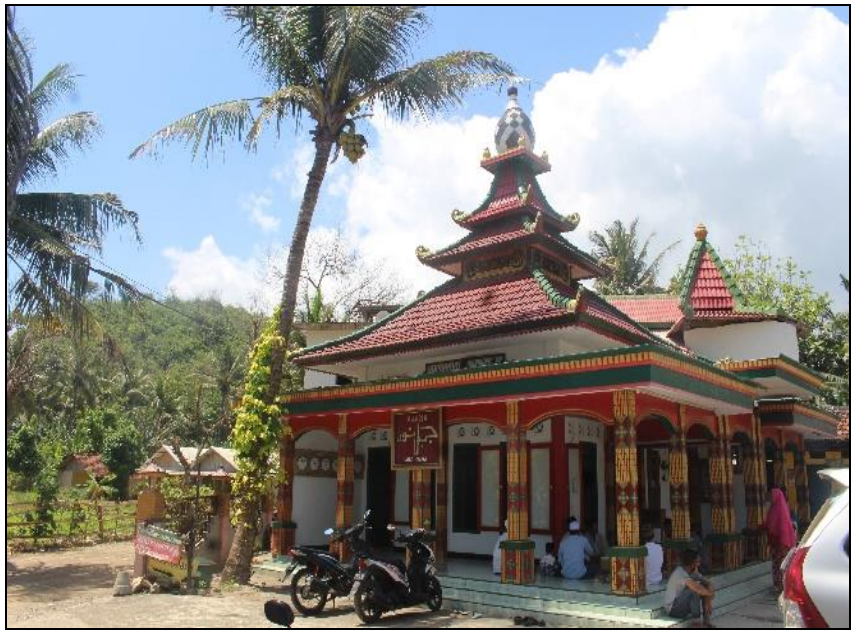

(a) Mosque in coastal area

(b) painted in specific red color of China

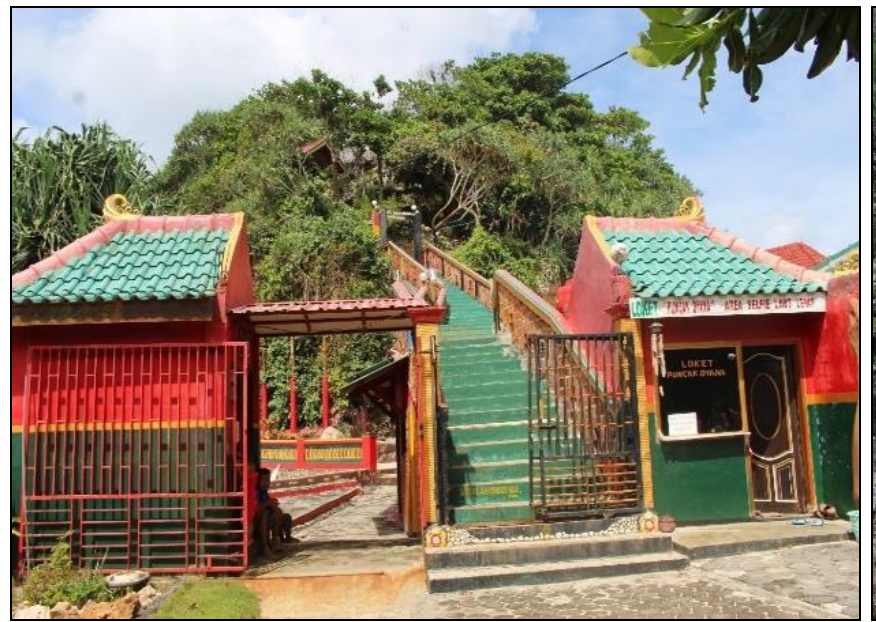

(c) Ticketing booths and entrances to Dyana Peak

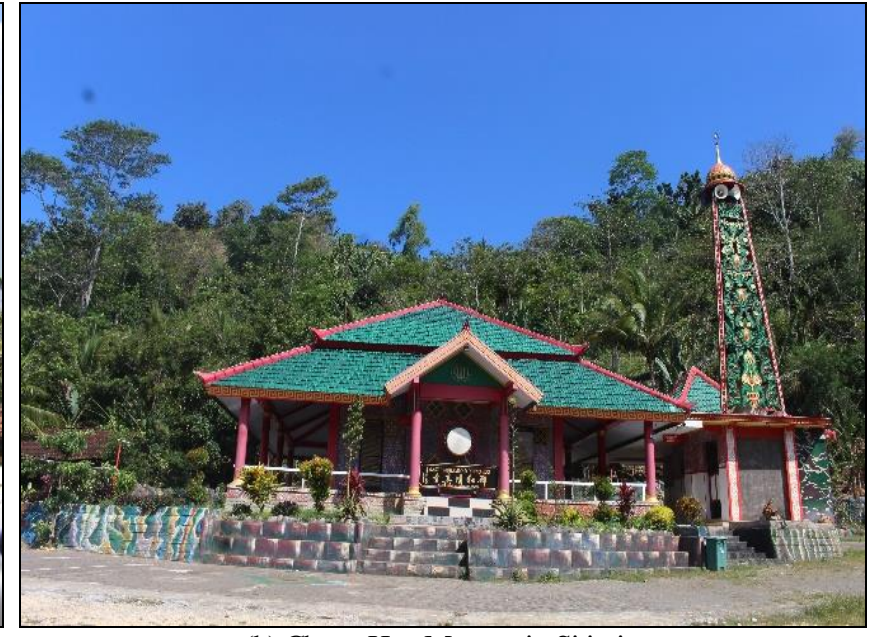

(b) Cheng Hoo Mosque in Sitiarjo village, donated by the Cheng Hoo Foundation

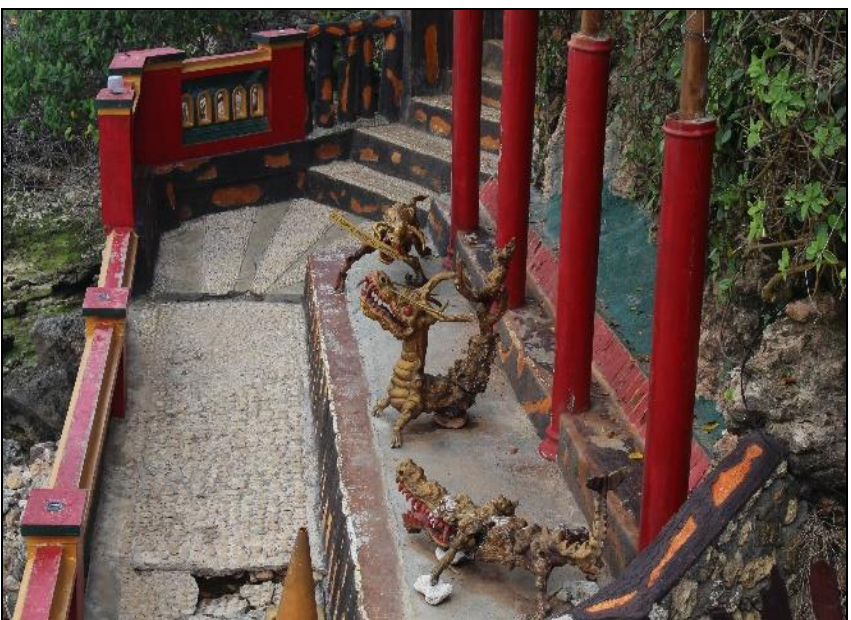

(d) The dragon headdress in front of the cave entrance

Figure 9. Acculturation of Islamic, Chinese, Hindu, and Culture on Goa China (China Cave) Beach

\section{CONCLUSION}

The results indicated that the beach carrying capacity is in a positive and strong condition. The coast development of Goa China affected the economy of inside and outside the community. Most of the people around the Goa China coast are 
original residents of Sitiarjo, Malang, but some people are from other areas looking for work, so it made harmonious and balanced culture in the village. Cultural acculturation is a unique attraction in the Goa China (China Cave). It is necessary to attract International tourist for visiting Goa China (China Cave) through promotion. further research needs to be carried out to inventory the physical potential as tourist attractions for Goa China (China Cave).

\section{Acknowledgements}

The research was supported by the communities, informants, research institutions, community service division and Department of Social Science, State University of Malang. The research was granted by the PNBP of State University of Malang for 2020. The research has no intention or conflict of interest toward individuals or groups.

\section{REFERENCES}

Arintoko, A., Ahmad, A.A., Gunawan, D.S., \& Supadi, S. (2020). Community-Based Tourism Village Development Strategies: A Case of Borobudur Tourism Village Area, Indonesia. GeoJournal of Tourism and Geosites, 29(2), 398-413. https://doi.org/10.30892/gtg.29202-477

Asmit, B., Syahza, A., Mahdum, A., \& Riadi, R.M. (2020). Opportunities and Prospect for Tourism Deveopmnet on Rupat Island, Indonesia. Folia Geographica, 62(2), 133-148.

Bengen, D. (2010). Maritime State Development Perspective. Indonesia Maritim Institute, Jakarta.

BPS. (2020). Kecamatan Sumbermanjing dalam Angka (Sumbermanjing in numbers). Badan Pusat Statistik Kota Malang (Central Statistics of Malang).

Dahuri, R., Rais, J., Ginting, S.P., \& Sitepu, M.J. (2001). Integrated Resource Management of the Coastal and Ocean Areas. Jakarta: PT. Pradnya Paramita.

Damanik, J., \& Weber, H.F. (2006). Perencanaan Ekowisata dari Teori ke Aplikasi (Ecotourism Planning: Theory to Application). Penerbit Andi.

Ernawati, N.M., Sanders, D., \& Dowling, R. (2017). Host-Guest Orientations of Community-Based Tourism Products: A Case Study in Bali, Indonesia. International Journal of Tourism Research, 19(3), 367-382. https://doi.org/10.1002/jtr.2119

Goodwin, H. (2002). Local Community Involvement in Tourism around National Parks: Opportunities and Constraints. Current Issues in Tourism, 5(3-4), 338-360. https://doi.org/10.1016/S0160-7383(98)00104-210.1080/13683500208667928

Haywood, K.M. (1988). Responsible and Responsive Tourism Planning in the Community. Tourism Management, 9(2), 105-118. https://doi.org/10.1016/0261-5177(88)90020-9

Herlambang, S. (2004). Dasar-Dasar Geomorfologi (Fundamental of Geomorphology). Jayadinata.

Hilman, Y.A., \& Kartika, T. (2020). Dinamika Kelembagaan Sektor Pariwisata di Kabupaten Ponorogo [The Changes in Tourism Office of Ponorogo]. Indonesian Journal of Tourism and Leisure, 1(1), 26-37. https://doi.org/10.36256/ijtl.v1i1.82

Jarvis, D., Stoeckl, N., \& Liu, H.B. (2016). The Impact of Economic, Social and Environmental Factors on Trip Satisfaction and the Likelihood of Visitors Returning. Tourism Management, 52, 1-18. https://doi.org/10.1016/S0160-7383(98)00104-210.1016/j.tourman.2015.06.003

Keyim, P. (2018). Tourism Collaborative Governance and Rural Community Development in Finland: The Case of Vuonislahti. Journal of Travel Research, 57(4), 483-494. https://doi.org/10.1016/S0160-7383(98)00104-210.1177/0047287517701858

Kodir, A. (2018). Tourism and Development: Land Acquisition, Achievement of Investment and Cultural Change (Case Study Tourism Industry Development in Batu City, Indonesia). GeoJournal of Tourism and Geosites, 21(1), 253-265. https://doi.org/10.30892/gtg. 2211112200--228855

Kodir, A, Tanjung, A., Sumarmi, Ahmad, R., \& Simanjuntak, T.B. (2019). Tourism Governance in Komodo National Park, Indonesia: Blessing or Curse?. GeoJournal of Tourism and Geosites, 27(4), 1401-1417. https://doi.org/10.30892/gtg.27424-443

Kurniawati, E., Sumarmi, S., \& Aliman, M. (2020). Participation of Green Environmental Group and Ulur-ulur Local Wisdom on Buret Lake Ecotourism Management in Karst Area of Tulungagung, Indonesia. GeoJournal of Tourism and Geosites, 30(2 supplement), 889-895. https://doi.org/10.30892/gtg.302spl15-519

Marlina, Sumarmi, \& Astina, I.K. (2020). Sustainable Marine Ecotourism Management: A Case of Marine Resource Conservation Based on Local Wisdom of Bajo Mola Community in Wakatobi National Park. GeoJournal of Tourism and Geosites, 32(4), 1317-1323. https://doi.org/10.30892/gtg.32419-575

Marlina, Sumarmi, Astina, I.K., \& Susilo, S. (2020). Social-Economic Adaptation Strategies of Bajo Mola Fishers in Wakatobi National Park. GeoJournal of Tourism and Geosites, 34(1), 14-19. https://doi.org/10.30892/gtg.34102-613

Moleong, L.J. (2004). Metodologi Penelitian Kualitatif [Qualitative Research Methodology]. PT Remaja Rosdakarya.

Munien, S., Gumede, A., Gounden, R., Bob, U., Gounden, D., \& Perry, N.S. (2019). Profile of Visitors to Coastal and Marine Tourism Locations in Cape Town, South Africa. GeoJournal of Tourism and Geosites, 27(4), 1134-1147. https://doi.org/10.30892/gtg.27402-421

Prabhakaran, S., Nair, V., \& Ramachandran, S. (2014). Community Participation in Rural Tourism: Towards a Conceptual Framework. Procedia - Social and Behavioral Sciences, 144, 290-295. https://doi.org/10.1016/j.sbspro.2014.07.298

Purnomo, A., Idris, I., \& Kurniawan, B. (2020). Understanding Local Community in Managing Sustainable Tourism at Baluran National Park-Indonesia. GeoJournal of Tourism and Geosites, 29(2). https://doi.org/10.30892/gtg.29210-485

Purwanto, P., Astina, I.K., \& Suharto, Y. (2015). Pemanfaatan Sistem Informasi Geografi untuk Pemodelan Spasial Pengembangan Wisata Pantai di Kabupaten Tulungagung. Jurnal Pendidikan Geografi: Kajian, Teori, dan Praktek dalam Bidang Pendidikan dan Ilmu Geografi, 20(1), 12-23. https://doi.org/10.17977/jpg.v20i1.281

Ramanda, P., Hakim, L., \& Pangestuti, E. (2020). Partisipasi Masyarakat dalam Pengelolaan Objek dan Daya Tarik Wisata Koridor Jalur Lintas Selatan Kabupaten Malang (Community Participation in the Tourism Management for the South Crossline of Malang). Profit: Jurnal Administrasi Bisnis, 14(1), 22-31. https://doi.org/10.21776/ub.profit.2020.014.01.3

Sugiyono (2014). Metode Penelitian Kuantitatif Kualitatif dan R\&D [Qualitative and Quantitative Research Methods $R \& D$ ]. Alfabeta.

Sumarmi, Kurniawati, E., \& Aliman, M. (2020). Community-Based Tourism (CBT) to Establish Blue Economy and Improve Public Welfare for Fishing Tourism Development in Klatak Beach, Tulungagung, Indonesia. GeoJournal of Tourism and Geosites, 31(3). https://doi.org/10.30892/gtg.31307-530

Suwantoro, G. (1997). Dasar-dasar Pariwisata [Tourism Basics]: Vol. Cetakan pertama. Penerbit Andi.

Thomas, R. (2007). Tourism Partnerships and Small Firms: Power, Participation and Partition. The International Journal of Entrepreneurship and Innovation, 8(1), 37-43. https://doi.org/10.5367/000000007780007344

Timothy, D.J. (1999). Participatory Planning a View of Tourism in Indonesia. Annals of Tourism Research, 26(2), $371-391$. https://doi.org/10.1016/S0160-7383(98)00104-210.1016/S0160-7383(98)00104-2

Yankholmes, A. (2018). Tourism as an Exercise in Three-Dimensional Power: Evidence from Ghana. Tourism Management Perspectives, 25, 1-12. https://doi.org/10.1016/j.tmp.2017.11.001 